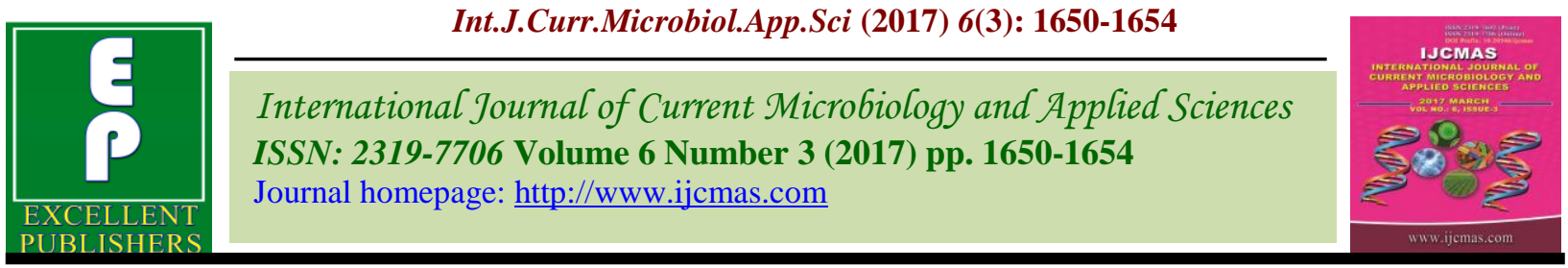

Original Research Article

https://doi.org/10.20546/ijcmas.2017.603.191

\title{
Genetic Diversity and Phylogenetic Relationship between Indigenous Cattle Breeds
}

\author{
S. Vani* and K. Sakunthala Devi \\ Department of Animal Genetics and Breeding \\ College of Veterinary Science, Proddatur, Y.S.R District, A.P - 516360, India \\ *Corresponding author
}

\begin{tabular}{|c|c|}
\hline & A B S T R A C T \\
\hline Keywords & \multirow{4}{*}{ 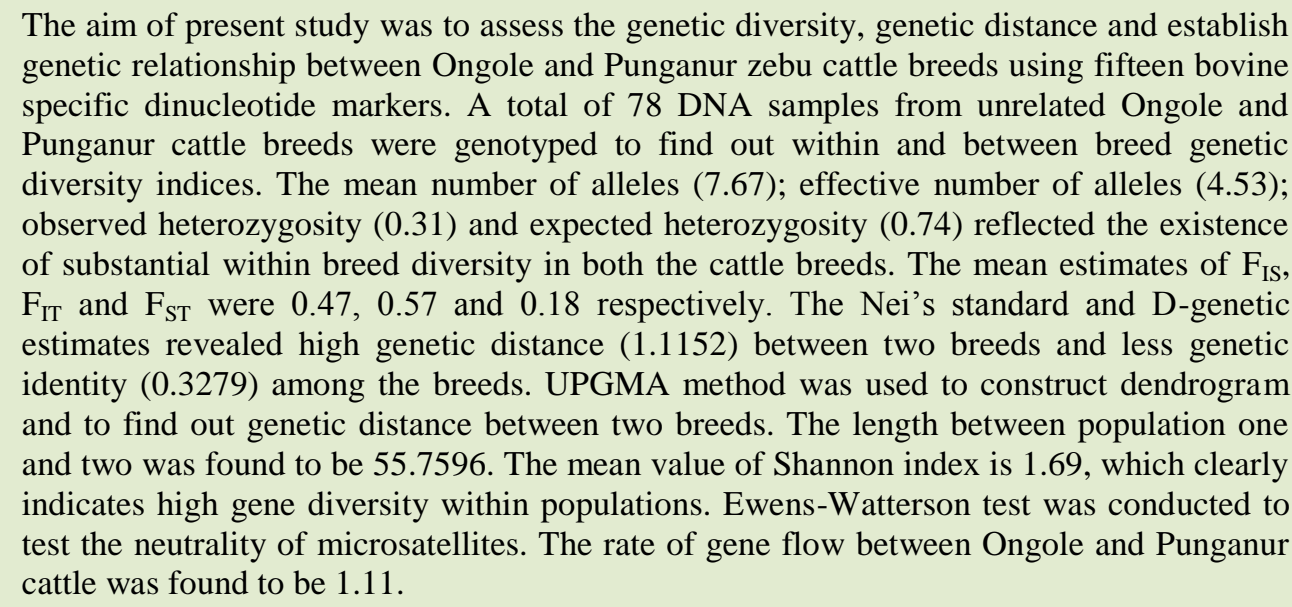 } \\
\hline $\begin{array}{l}\text { Genetic } \\
\text { relationship, } \\
\text { Genetic distance, } \\
\text { Phylogenetic } \\
\text { analysis, } \\
\text { Microsatellite } \\
\text { markers, Zebu } \\
\text { cattle. }\end{array}$ & \\
\hline Article Info & \\
\hline $\begin{array}{l}\text { Accepted: } \\
\text { 24 February } 2017 \\
\text { Available Online: } \\
10 \text { March } 2017\end{array}$ & \\
\hline
\end{tabular}

\section{Introduction}

Zebu breeds of cattle from southern part of India are well known for their adaptability to extreme climatic conditions, draught efficiency, disease resistance and poor nutritional environment. Selection of appropriate populations for conservation of such genetic resources is needed in view of preventing rapid erosion of animal genetic resources. Estimation of genetic diversity is essential to decide the priority of the population to be conserved. DNA- based molecular markers with high level of polymorphism have been used to evaluate genetic variation of breeds in breeding programmes and conservation. Micro satellites are the potential markers to study genetic variation, gene flow, genetic distance and genetic identity of indigenous cattle breeds.

Ongole is the dual purpose breed of cattle from southern part of India belongs to geographical area of Ongole town in Andhra Pradesh, constitutes about 5\% of the total cattle population and belongs to short horned group of zebu. Ongole is one of the best cattle breeds of the country with majestic-looking, huge in size, extremely docile, hardiness, 
faster growth rate, adoptability and suitable for steady, heavy draught under harsh tropical conditions. It is considered as mute ambassador to several countries in the development of some of exotic beef breeds like American Brahman and Santa getrudis etc. Mechanization, unplanned and indiscriminate breeding among native stocks directly or indirectly lead to the dilution of Ongole cattle germplasm. Hence, there is an urgent need to conserve the animal genetic resources of this breed.

Punganur is a one of the dwarf and dual purpose cattle breed of A.P. Since the population size is declining in number, efforts have been in progress now for its conservation. The present study was carried out to find out the genetic diversity and genetic relationship among Ongole and Punganur cattle breeds by using microsatellite analysis.

\section{Materials and Methods}

Blood samples were collected from 39 Ongole and Punganur cattle and Genomic DNA was isolated as per procedure of Sambrook and Russell, 2001. A total of 15 microsatellite markers chosen randomly from the list recommended by FAO were amplified using a thermal cycler with a PCR reaction mixture $(12.5 \mu 1)$ containing $25 \mathrm{mM} \mathrm{Mgcl}_{2}$, $10 \mathrm{mM}$ dNTPs, 10x buffer, 60pM of each primer, 50ng of template DNA and 1 unit of Taq DNA polymerase. The PCR products were genotyped using $6 \%$ denaturing polyacrylamaide gel and then visualized after silver staining. The allele sizes were determined with the help of $50 \mathrm{bp}$ DNA marker. Samples were scored by using quantity one and genotyper 2.3 software, verified manually either as homo or heterozygote for each loci. Allelic profile was calculated using the POPGENE 1.31 software version (Yeh et al., 1999). Shannon index was calculated for determining diversity index
(Shannon \& Weaver, 1949). Polymorphism information content was calculated using PIC calculator. The mutation drift equilibrium was tested using the software bottleneck 1.2.02 version (Piry et al.,1999) by using all the three mutation models.

\section{Results and Discussion}

The observed, effective number of alleles, Shannon's index, observed, expected heterozygosity and Polymorphism information content were presented in table 1 .

A total of 115 alleles were observed across all loci. The observed number of alleles ranged from 4 (ILSTS005, ILSTS006, INRA005) to 12 (ETH010, HEL001, CSRM060, INRA037) with a mean of $7.67 \pm 3.10$.The effective number of alleles in both the breeds across all the loci ranged from 1.63 to 7.07 with a mean of $4.53 \pm 1.69$. Some of the alleles screened for microsatellite markers were found to be specific to a particular breed.

The observed heterozygosity was highest for CSRM060 (0.87) and no heterozygosity was observed with ILSTS006 (Zero) with a overall mean of $0.31 \pm 0.25$. The expected heterozygosity was observed to be $0.74 \pm 0.13$ across all loci and ranged from 0.39 (INRA032) to 0.84 (INRA037).

All the fifteen microsatellite markers were found to be polymorphic in nature with the mean PIC value of $0.61 \pm 0.20$ across all loci. The loci ETH010 was found to have a highest PIC value (0.83) whereas the locus ILSTS005 has a lowest PIC value (0.18). In general, fairly high PIC values for majority of markers applied are suggestive of their utility in biodiversity evaluation of native Indian cattle breeds.

The Shannon's index is a parameter for determining diversity index. 
Table.1 Summary of genetic variation and heterozygosity in Ongole and Punganur breeds

\begin{tabular}{|l|l|l|l|l|l|l|l|}
\hline Locus & $\begin{array}{l}\text { Sample } \\
\text { Size }\end{array}$ & $\mathrm{n}_{\mathrm{a}}$ & $\mathrm{n}_{\mathrm{e}}$ & $\mathrm{I}$ & $\mathrm{H}_{0}$ & $\mathrm{H}_{\mathrm{e}}$ & $\mathrm{PIC}$ \\
\hline ETH010 & 78 & 12 & 6.15 & 2.09 & 0.41 & 0.84 & 0.83 \\
\hline ILSTS005 & 78 & 4 & 2.45 & 1.02 & 0.07 & 0.60 & 0.18 \\
\hline TGLA122 & 78 & 8 & 5.43 & 1.83 & 0.10 & 0.82 & 0.67 \\
\hline INRA035 & 78 & 9 & 3.70 & 1.70 & 0.51 & 0.73 & 0.49 \\
\hline INRA063 & 78 & 5 & 4.24 & 1.52 & 0.05 & 0.77 & 0.53 \\
\hline HEL001 & 78 & 12 & 4.06 & 1.81 & 0.25 & 0.76 & 0.57 \\
\hline TGLA126 & 78 & 7 & 5.60 & 1.81 & 0.61 & 0.83 & 0.76 \\
\hline INRA005 & 78 & 4 & 2.84 & 1.14 & 0.10 & 0.65 & 0.38 \\
\hline ILSTS006 & 78 & 4 & 2.30 & 0.99 & 0.00 & 0.57 & 0.26 \\
\hline INRA032 & 78 & 5 & 1.63 & 0.77 & 0.10 & 0.39 & 0.67 \\
\hline ETH225 & 78 & 6 & 4.70 & 1.60 & 0.56 & 0.79 & 0.82 \\
\hline CSRM060 & 78 & 12 & 7.07 & 2.18 & 0.87 & 0.86 & 0.72 \\
\hline BM1824 & 78 & 7 & 5.16 & 1.76 & 0.23 & 0.81 & 0.72 \\
\hline TGLA053 & 78 & 8 & 5.72 & 1.85 & 0.41 & 0.83 & 0.82 \\
\hline INRA037 & 78 & 12 & 6.94 & 2.14 & 0.43 & 0.86 & 0.66 \\
\hline Mean & $\mathbf{7 8}$ & $\mathbf{7 . 6 7}$ & $\mathbf{4 . 5 3}$ & $\mathbf{1 . 6 1}$ & $\mathbf{0 . 3 1}$ & $\mathbf{0 . 7 4}$ & $\mathbf{0 . 6 1}$ \\
\hline Std.dev & & 3.10 & 1.69 & 0.44 & 0.25 & 0.13 & 0.20 \\
\hline
\end{tabular}

$\mathrm{n}_{\mathrm{a}}=$ Observed number of alleles; $\mathrm{n}_{\mathrm{e}}=$ Effective number of alleles; $\mathrm{I}=$ Shannon's information index

Table.2 Summary of F-Statistics and gene flow for all loci in Ongole and Punganur cattle

\begin{tabular}{|l|l|l|l|l|}
\hline Locus & $\mathrm{F}_{\text {IS }}$ & $\mathrm{F}_{\mathrm{ST}}$ & $\mathrm{F}_{\mathrm{IT}}$ & $\mathrm{N}_{\mathrm{e}} \mathrm{m}$ \\
\hline ETH010 & 0.50 & 0.01 & 0.50 & 35.88 \\
\hline ILSTS005 & 0.62 & 0.65 & 0.87 & 0.133 \\
\hline TGLA122 & 0.85 & 0.15 & 0.87 & 1.33 \\
\hline INRA035 & 0.03 & 0.28 & 0.30 & 0.63 \\
\hline INRA063 & 0.91 & 0.23 & 0.93 & 0.83 \\
\hline HEL001 & 0.55 & 0.24 & 0.66 & 0.76 \\
\hline TGLA126 & 0.21 & 0.04 & 0.24 & 5.90 \\
\hline INRA005 & 0.72 & 0.43 & 0.84 & 0.32 \\
\hline ILSTS006 & 1.00 & 0.52 & 1.00 & 0.22 \\
\hline INRA032 & 0.66 & 0.20 & 0.73 & 1.00 \\
\hline ETH225 & 0.20 & 0.08 & 0.27 & 2.77 \\
\hline CSRM060 & -0.04 & 0.02 & -0.01 & 9.07 \\
\hline BM1824 & 0.69 & 0.06 & 0.72 & 3.35 \\
\hline TGLA053 & 0.44 & 0.10 & 0.49 & 2.19 \\
\hline INRA037 & 0.47 & 0.02 & 0.49 & 9.10 \\
\hline Mean & $\mathbf{0 . 4 7}$ & $\mathbf{0 . 1 8}$ & $\mathbf{0 . 5 7}$ & $\mathbf{1 . 1 1}$ \\
\hline
\end{tabular}

$\mathrm{Nm}=$ Gene flow estimated from $\mathrm{F}_{\mathrm{ST}}=0.25\left[1-\mathrm{F}_{\mathrm{ST}}\right] / \mathrm{F}_{\mathrm{ST}}$ 
Table.3 Nei's original measure of Genetic distance (below diagonal) and Genetic identity (above diagonal)

\begin{tabular}{|l|l|l|}
\hline Population & Ongole & Punganur \\
\hline Ongole & $* * * *$ & 0.3279 \\
\hline Punganur & 1.1152 & $* * * *$ \\
\hline
\end{tabular}

Table.4 The overall Ewens-Watterson test for neutrality (statistics of natural selection)

\begin{tabular}{|l|l|l|l|l|l|l|l|}
\hline Locus & Obs. F & Min F & Max F & Mean & SE & L95 & U95 \\
\hline ETH010 & 0.16 & 0.08 & 0.75 & 0.20 & 0.00 & 0.12 & 0.41 \\
\hline ILSTS005 & 0.40 & 0.25 & 0.92 & 0.54 & 0.02 & 0.29 & 0.90 \\
\hline TGLA122 & 0.18 & 0.12 & 083 & 0.31 & 0.01 & 0.17 & 0.60 \\
\hline INRA035 & 0.26 & 0.11 & 0.81 & 0.28 & 0.00 & 0.16 & 0.54 \\
\hline INRA063 & 0.23 & 0.20 & 0.90 & 0.48 & 0.02 & 0.25 & 0.83 \\
\hline HEL001 & 0.24 & 0.08 & 0.75 & 0.21 & 0,00 & 0.12 & 0.40 \\
\hline TGLA126 & 0.17 & 0.14 & 0.85 & 0.35 & 0.01 & 0.19 & 0.68 \\
\hline INRA005 & 0.35 & 0.25 & 0.92 & 0.54 & 0.02 & 0.30 & 0.87 \\
\hline ILSTS006 & 0.43 & 0.25 & 0.92 & 0.55 & 0.02 & 0.31 & 0.90 \\
\hline INRA032 & 0.61 & 0.20 & 0.90 & 0.48 & 0.02 & 0.26 & 0.83 \\
\hline ETH225 & 0.10 & 0.16 & 0.88 & 0.39 & 0.01 & 0.22 & 0.72 \\
\hline CSRM060 & 0.14 & 0.08 & 0.75 & 0.20 & 0.01 & 0.12 & 0.38 \\
\hline BM1824 & 0.19 & 0.14 & 0.85 & 0.36 & 0.00 & 0.20 & 0.68 \\
\hline TGLA053 & 0.17 & 0.12 & 0.83 & 0.31 & 0.01 & 0.17 & 0.60 \\
\hline INRA037 & 0.14 & 0.08 & 0.75 & 0.21 & 0.00 & 0.12 & 0.38 \\
\hline
\end{tabular}

The Shannon's index values ranged from 0.77 (INRA032) to 2.18 (CSRM060) with a mean value of $1.61 \pm 0.44$ which clearly indicates the existence of gene diversity in the population. The high amount of variation indicates scope for conservation. These results were in accordance with the reported values of Thakur et al., 2010 and Thiagarajan et al., 2012. In general, the average higher values of genetic diversity indices observed indicate the basis of its heterogenous nature being represented by two morphologically different groups of animals.

\section{Gene differentiation}

The mean estimates of F-statistics (Wright's fixation indices) obtained to measure the deviations of genotypic frequencies using three parameters, within population inbreeding estimate $\left(\mathrm{F}_{\mathrm{IS}}\right)$, measurement of population differentiation $\left(\mathrm{F}_{\mathrm{ST}}\right)$, Total inbreeding estimate $\left(\mathrm{F}_{\mathrm{IT}}\right)$, and Gene flow $\left(\mathrm{N}_{\mathrm{e}} \mathrm{m}\right)$ among the breeds are shown in table 2. The within population inbreeding estimate $\left(\mathrm{F}_{\mathrm{IS}}\right)$ which indicate hetrozygosity deficit ranged from 0.04 to 0.91 with a mean of 0.47 whereas the total population had a heterozygosity deficit of 0.57 that ranged from -0.01 to 0.93 . The $\mathrm{F}_{\mathrm{ST}}$ estimates for gene differentiation values ranged from 0.01 to 0.65 across all loci. The highest degree of genetic differentiation between Ongole and Punganur was found to be supported by relatively low level of gene flow (1.11) between these two breeds (Table 2). Number of factors Viz., inbreeding, locus under selection, null alleles (non amplifying alleles), wahlund effect are responsible for lack of heterozygotes in the population (Nei, 1987). The high homogeneity or lack of heterozygotes among these breeds might be due to inbreeding or non random mating as evidenced by overall positive F-value. The high $\mathrm{F}_{\text {IS }}$ values resulted were might be due to small sample size (Metta, 2004). Negative $F_{I S}$ values (-0.04) were exhibited by CSRM060, which suggests that $4 \%$ of heterozygous excess individuals are available in the population and the samples were collected from highly heterogenous population. 
Nei's standard $\left(D_{S}\right)$ and $\left(D_{A}\right)$ genetic distance values showed highest degree of divergence between Ongole and Punganur breeds (Table 3). Nei's original measure of genetic distance was calculated using UPGMA method. The $\mathrm{D}_{\mathrm{A}}$ based genetic distance values revealed high (1.1152) levels of differentiation between the two native cattle breeds of Andhra Pradesh. Genetic distance estimates were used to calculate the divergence time ( $\mathrm{t}$ in generation) between the two breeds as calculated as $\mathrm{D}=2 \alpha \mathrm{t}$, whereas ' $\mathrm{D}$ ' is the standard genetic distance, Nei and ' $\alpha$ ' is the assumed mutation rates of microsatellite loci $\left(1.2 \times 10^{-3}\right)$

Assuming a constant rate of divergence and a generation interval of 5-6 years, the estimated time of divergence between Ongole and Punganur cattle based on Nei's genetic distance were 464 generations (2320 years).

Ewen's- Watterson test was performed to test the neutrality for microsatellite markers. The statistics $\mathrm{F}$ (sum of squares of allele frequency) \& limit (upper and lower) at 95\% confidence region for the test were calculated using the algorithm by Manly method utilizing 1000 simulations and implemented in Popgene software. The overall test for neutrality across the two populations revealed that observed F-values for some of the loci were within the lower and upper limits of the 95\% confidence interval (Deepika et al., 2012) (Table 4).

In conclusion the present study is useful attempt to understand genetic diversity of two Zebu cattle breeds using microsatellite DNA markers and there is a need of genetic management to reduce the inbreeding and intermixing. Further investigations would be required to clarify the relationship between the two cattle breeds of Andhra Pradesh.

\section{References}

Deepika and Raj kumar Salar. 2012. Genetic diversity and bottleneck analysis of Indigenous Grey cattle Breeds of India based on Microsatellite data., 174-183.

Metta, M., Kanginakudru, S., Gudiseva, N. and Nagaraju, J. 2004. Genetic characterization of Indian cattle breeds, Ongole and Deoni (Bos indicus) using microsatellite markers A Preliminary study. BMC Genetics, 5: 16.

Nei, M. 1987. Molecular evolutionary Genetics. Coumbia University Press, New York, USA.

Piry, S., Luikart, G. and Cornuet, J.M. 1999. Bottleneck a computer programme for detecting recent effective population size reductions from allele data frequencies, $J$. Hered., 90: 502-503.

Sambrook, J. and Russel, D. 2001. Molecular cloning. A laboratory manual. Cold spring Harbour Laboratory press, Cold spring Harbour, New York.

Shannon, C.E. and Weaver, W. 1949. The mathematical theory of communication. (University of Illinois Press IL)

Thakur, S.S., Parmar, S.N.S., Joshi, C.G., Thakur, M.S., Sharma, R and Chaudari, M.V. 2010. Genetic characterization of Malvi cattle using microsatellite markers. Ind. J. Anim. Sci., 80: 138-41.

Thiagarajan, R. 2012. Genetic diversity and bottleneck analysis of Umblacherry cattle by Microsatellite markers. CIB Tech. J. Biotechnol., 2(1): 28-33.

Yeh, F.C., Boyle, T., Rongcai, Y., Ye, Z and Xian, J.M. Popgene. 1999. Version 1.31, A Microsoft Window Based Free Ware for Population Genetic Analysis, University of Alberta and Centre for International Forestry Research, Edmonton.

\section{How to cite this article:}

Vani, S. and Sakunthala Devi, K. 2017. Genetic Diversity and Phylogenetic Relationship between Indigenous Cattle Breeds. Int.J.Curr.Microbiol.App.Sci. 6(3): 1650-1654. doi: https://doi.org/10.20546/ijcmas.2017.603.191 